\title{
Assessment of odour awareness of indoor pollution among rural and urban homemakers of Ludhiana city
}

\author{
D. KAUR, M. SIDHU AND S. BAL
}

Article Chronicle :

Received :

29.09.2015;

Revised :

21.10.2015;

Accepted :

06.11 .2015

Key Words : Indoor pollution, Negative odour, Odour awareness, Positive odour, Unpleasant odour
ABSTRACT : There seem to be substantial individual differences in the role that odours play in people's lives. Whereas some individuals are always spontaneously commenting on any odour in the room, others only notice these features after they have been pointed out to them. This characteristic is most likely related to individual differences. Being capable of quickly assessing people's odour awareness may prove useful in predicting their reactions to environmental odours in various indoor settings where annoyance or adverse health effects may be an issue. Keeping the concern and significance of indoor pollution in mind a study was planned with the objective to assess the indoor pollution subjectively from rural and urban houses". A modified 'Odour Awareness Scale' (OAS) was used. Study revealed that according to 'Odour Awareness Scale' people have different abilities to get attracted to differentiate and get repelled by indoor odours. Maximum awareness was for the positive/ pleasant odours (Mean score $=3.73$ ) which meant noticing the pleasant odour of fresh leaves and flowers both indoors and outdoors, smell of cooking food from own kitchen and neighborhood's; and getting aware of pleasant odour in air. The awareness was high for rural respondents (Mean score = 3.81) as compared to urban (Mean score $=3.64$ ). Unpleasant odour awareness was next in the order (Mean score $=3.70$ ); and it was higher amongst urban respondents (Mean score $=3.75$ ) in comparison to rural counterparts (Mean score $=3.64$ ). Negative odours included general unpleasant smell prevailing in the environment, smell of used, soiled clothes and smell of burnt food or smoked milk.

HOW TO CITE THIS ARTICLE : Kaur, D., Sidhu, M. and Bal, S. (2015). Assessment of odour awareness of indoor pollution among rural and urban homemakers of Ludhiana city. Asian J. Environ. Sci., 10(2): 120-125.

Author for correspondence :

\section{KAUR}

Department of Family

Resource Management,

College of Home Science

Punjab Agricultural

University, LUDHIANA

(PUNJAB) INDIA

See end of the article for

Coopted authors' 